ECONOMIC GROWTH CENTER

YALE UNIVERSITY

P.O. Box 208629

New Haven, CT 06520-8269

http://www.econ.yale.edu/ egcenter/

CENTER DISCUSSION PAPER NO. 943

\title{
Successful Transition towards a Virtuous Cycle of Human Development and Economic Growth: Country Studies
}

\author{
Gustav Ranis \\ Yale University \\ Frances Stewart \\ Oxford University
}

September 2006

Notes: Center Discussion Papers are preliminary materials circulated to stimulate discussions and critical comments.

Gustav Ranis is the Frank Altschul Professor Emeritus of International Economics at Yale University. Frances Stewart is Professor of Development Economics at Oxford University and Director of the Centre for Research on Inequality, Human Security and Ethnicity at Queen Elizabeth House, Oxford. We thank David Corderi and Yili Dong for extremely valuable research assistance and the Carnegie Corporation for its generous support.

This paper can be downloaded without charge from the Social Science Research Network electronic library at: http://ssrn.com/abstract=920603

An index to papers in the Economic Growth Center Discussion Paper Series is located at: http://www.econ.yale.edu/ egcenter/research.htm 


\section{Successful Transition towards a Virtuous Cycle of Human Development and Economic Growth: Country Studies}

\section{Gustav Ranis and Frances Stewart}

This paper explores the two-way links between Economic Growth and Human Development by examining the performance of some countries which have been successful in both dimensions and a few which have not. The specific aim is to examine the historical experience of six countries in order to determine how a system can move to a situation in which improvements in Human Development accompany and support higher rates of growth which, in turn, contribute to further improvements in Human Development as the basic societal objective.

Keywords: Economic Growth, Human Development, Comparative Country Studies

JEL Codes: O11, O15, O57 


\title{
Successful Transition towards a Virtuous Cycle of Human Development and Economic Growth: Country Studies
}

\author{
Gustav Ranis and Frances Stewart*
}

\section{INTRODUCTION}

Human Development (HD) and Economic Growth (EG) are closely linked in a twoway process. EG is a prime contributor to sustained progress in HD, while improvements in HD not only contribute to the fundamental development goal, but HD is itself also a critical input into EG over time. This paper explores how countries can achieve success on both HD and EG by analyzing the experience of some countries which achieved sustained improvements in both as well as some whose poor HD led to failure to sustain EG.

Exploration of the two-way links between HD and EG has provided empirical evidence of the strength of these relationships (Ranis and Stewart 2006). Because of the mutual causation between HD and EG, countries tend to fall into virtuous or vicious cycle categories, i.e. relatively strong HD promotes EG, and relatively strong EG promotes HD, causing a virtuous cycle; conversely weak HD holds back EG which in turn holds back improvements in HD in a vicious cycle. Some countries, however, show what we describe as 'lop-sided' categories, with weakness on one side but not on the other. Thus, countries with relatively strong EG but weak HD improvement are described as 'EG-lopsided', while countries with weak EG and strong HD are described as 'HD-lopsided'. Tracing a country's progress decade by decade shows movement over time in and out of the four categories. Earlier work indicates that countries rarely persist in a lop-sided category because, the weak side acts as a brake, bringing the country back into a vicious cycle, unless there is some policy change which strengthens the lagging dimension, allowing the country to move into a virtuous cycle (Ranis and Stewart 2006).

From a development perspective, the desirable category to be in is, of course, the virtuous one. Countries initially in a vicious cycle may, in principle, get there in a variety of ways, i.e. going first from vicious to EG or HD lopsided; and then from HD-lopsided or EGlopsided to virtuous. Our aim in this paper is to explore how countries can make the transition from a worse to a better situation, in order to glean some general lessons about how countries currently doing less well may move up the ladder and into the virtuous category. We are also interested in exploring why countries in an EG-lopsided category almost always fall back into the vicious cycle instead of moving up into the virtuous cycle, while many in an HD-lopsided position seem able to move into the virtuous cycle.

Section II of this paper indicates the methodology adopted in order to classify countries into the four categories described above and presents the results of a decade by decade classification of all developing countries. From this we can identify a sample of countries that have switched categories in the period 1960-2001. We then select a few of these cases for in-depth exploration into the causes of their success in moving to preferred positions, as well as examining some cases of countries failing to make this transition and falling back from an EG-lopsided position into a vicious cycle. In section III we present these country studies, while section IV draws some general conclusions.

\footnotetext{
* Gustav Ranis is the Frank Altschul Professor Emeritus of International Economics at Yale University. Frances Stewart is Professor of Development Economics at Oxford University and Director of the Centre for Research on Inequality, Human Security and Ethnicity at Queen Elizabeth House, Oxford. We thank David Corderi and Yili Dong for extremely valuable research assistance and the Carnegie Corporation for its generous support.
} 


\section{COUNTRY CLASSIFICATION}

Countries are classified into the four categories mentioned above according to whether they perform above or below the average of all developing countries with respect to improvements in HD and EG, from 1960 to 2001. ${ }^{1}$ HD improvements are defined as shortfall reductions ${ }^{2}$ in infant mortality rates, while EG is measured using PPP dollars. The results are shown in Diagram 1. As can be seen, the most populated quadrants are the vicious cycle and the HD-lopsided cycle, with the virtuous cycle mainly represented by the East Asian countries and the vicious cycle by countries in Sub-Saharan Africa.

Performing the same exercise decade by decade enables us to classify countries in each decade and thereby trace their transition path (see Table 1). Quite a lot of movement in and out of categories can be observed. The vicious cycle category proved fairly stable, with18 countries remaining there over the four decades; in contrast, only two countries remained in the virtuous cycle category throughout; four countries stayed in the HD-lopsided category, but it should be noted that no country remained in the EG-lopsided category. In terms of making progress, 6 countries out of 80 moved from the vicious cycle category to the HDlopsided one; and 13 moved from HD-lopsided into the virtuous category. In terms of regress,

\section{Diagram 1: HD and EG Performance, 1960-2000}

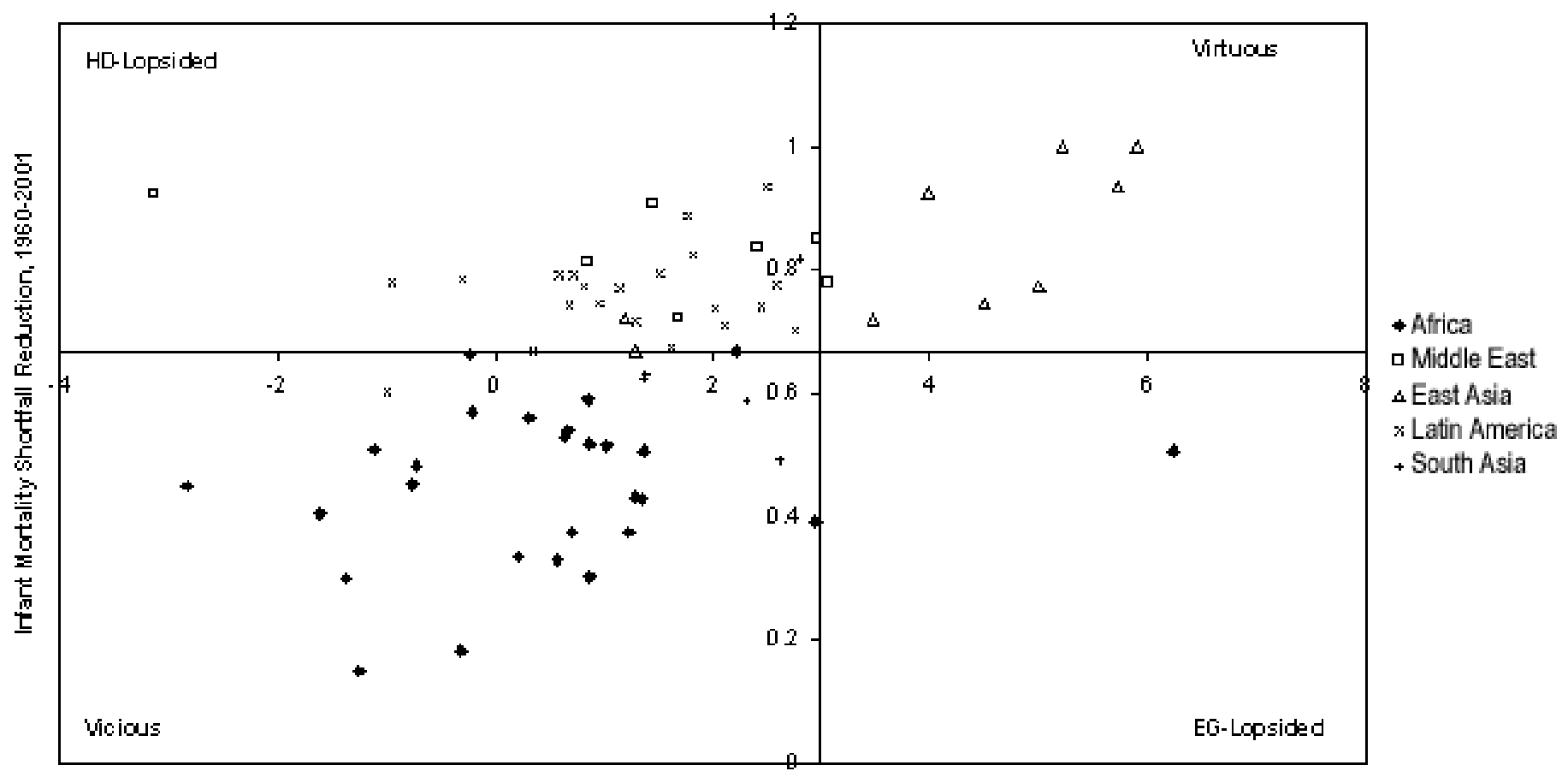

Average Annual GDP Per Capita Growth, 1960-2001

\footnotetext{
1 The all developing country average is weighted for population size of each country.

2 i.e. reductions in a the gap between a country's performance and that of the best performing country.
} 
only three countries moved downward from HD-lopsided to vicious, but 19 moved from EGlopsided to vicious, and just 2 jumped from EG-lopsided to HD-lopsided. The three HDlopsided countries that moved to the vicious category all suffered from severe civil war. This confirms the view that HD-lopsidedness tends to permit upward movement while EGlopsidedness is an unstable category and one that usually leads to a downward movement.

Since our prime objective in this paper is to understand country transitions towards success we selected two countries which moved in stages from a vicious to a virtuous category, i.e. China and Vietnam; one country that moved from HD-lopsided to virtuous (Chile); and one country that moved from vicious to HD-lopsided (Turkey). We also analyzed two unsuccessful countries that fell into the common pattern of a movement from EG-lopsided back to vicious (Nigeria and Pakistan). In each case our aim was to identify which links relating EG to HD and HD back to EG seemed to be critical in permitting countries to move forward; and conversely, which were the weak links causing the two laggard country cases to regress. We also hope to shed light on some broader political economy dimensions that underly these transitions.

Table 1

Virtuous, Vicious and Lop-Sided Performance, 1960-2001

Africa
Benin
Botswana
Burkina Faso
Burundi
Cameroon
Central African Republic
Chad
Congo, Dem. Rep.
Congo, Rep.
Cote d'Ivoire
Ethiopia
Gabon
Gambia
Ghana
Guinea-Bissau
Kenya
Lesotho
Madagascar
Malawi
Mali
Mauritania
Mauritius
Mozambique

\begin{tabular}{ccc} 
Vicious & Vicious & Vicious \\
Virtuous & Virtuous & Virtuous \\
Vicious & Vicious & Vicious \\
EG-Lopsided & Vicious & Vicious \\
Vicious & EG-Lopsided & Vicious \\
Vicious & Vicious & Vicious \\
Vicious & Vicious & Vicious \\
Vicious & Vicious & Vicious \\
Virtuous & Virtuous & Vicious \\
EG-Lopsided & Vicious & Vicious \\
- & - & Vicious \\
EG-Lopsided & EG-Lopsided & Vicious \\
- & Vicious & Vicious \\
HD-Lopsided & Vicious & Vicious \\
- & Vicious & Vicious \\
HD-Lopsided & Virtuous & HD-Lopsided \\
EG-Lopsided & EG-Lopsided & Vicious \\
Vicious & Vicious & Vicious \\
EG-Lopsided & EG-Lopsided & Vicious \\
- & Vicious & Vicious \\
EG-Lopsided & Vicious & Vicious \\
- & - & Virtuous \\
- & - & Vicious \\
\hline
\end{tabular}

Vicious

HD-Lopsided

Vicious

Vicious

Vicious

Vicious

Vicious

Vicious

Vicious

Vicious

Vicious

Vicious

Vicious

Vicious

Vicious

HD-Lopsided

Vicious

Vicious

Vicious

Vicious

Vicious

HD-Lopsided

EG-Lopsided 
Namibia

Niger

Nigeria

Rwanda

Senegal

Sierra Leone

South Africa

Sudan

Togo

Zambia

Zimbabwe

$\begin{array}{cc}- & - \\ \text { Vicious } & \text { Vicious } \\ \text { EG-Lopsided } & \text { Vicious } \\ \text { Vicious } & \text { Vicious } \\ \text { Vicious } & \text { Vicious } \\ \text { EG-Lopsided } & \text { Vicious } \\ \text { Virtuous } & \text { HD-Lopsided } \\ \text { Vicious } & \text { Vicious } \\ \text { EG-Lopsided } & \text { Vicious } \\ \text { HD-Lopsided } & \text { Vicious } \\ \text { Virtuous } & \text { HD-Lopsided }\end{array}$

$\begin{array}{cc}\text { Vicious } & \text { Vicious } \\ \text { Vicious } & \text { Vicious } \\ \text { Vicious } & \text { Vicious } \\ \text { Vicious } & \text { Vicious } \\ \text { Vicious } & \text { Vicious } \\ \text { Vicious } & \text { Vicious } \\ \text { HD-Lopsided } & \text { HD-Lopsided } \\ \text { Vicious } & \text { EG-Lopsided } \\ \text { Vicious } & \text { Vicious } \\ \text { Vicious } & \text { Vicious } \\ \text { HD-Lopsided } & \text { HD-Lopsided }\end{array}$

\section{Middle East}

Algeria
Egypt, Arab Rep.
Iran, Islamic Rep.
Jordan
Kuwait
Morocco
Oman
Saudi Arabia
Syrian Arab Republic
Tunisia
Turkey
United Arab Emirates
East Asia
China
Hong Kong, China
Indonesia
Korea, Rep.
Lao PDR
Malaysia
Mongolia
Papua New Guinea
Philippines
Singapore
Thailand
Vietnam

Vicious
EG-Lopsided
-
-

HD-Lopsided

EG-Lopsided

EG-Lopsided

EG-Lopsided

Virtuous

EG-Lopsided

$-$

$$
\begin{aligned}
& \text { EG-Lopsided } \\
& \text { EG-Lopsided } \\
& \text { Vicious }
\end{aligned}
$$

HD-Lopsided

EG-Lopsided

Vicious

EG-Lopsided

Virtuous

EG-Lopsided

Vicious

HD-Lopsided

\section{Vicious \\ Vicious \\ Vicious}

HD-Lopsided

HD-Lopsided

Vicious

Virtuous

HD-Lopsided

HD-Lopsided

HD-Lopsided

Vicious

HD-Lopsided
HD-Lopsided

Vicious

HD-Lopsided

HD-Lopsided

HD-Lopsided

Vicious

HD-Lopsided

HD-Lopsided

HD-Lopsided

HD-Lopsided

HD-Lopsided

$\begin{array}{cc}\text { HD-Lopsided } & \text { Virtuous } \\ \text { Virtuous } & \text { Virtuous } \\ \text { Virtuous } & \text { EG-Lopsided } \\ \text { Virtuous } & \text { Virtuous } \\ - & - \\ \text { Virtuous } & \text { Virtuous } \\ - & - \\ \text { EG-Lopsided } & \text { Vicious } \\ \text { Virtuous } & \text { Virtuous } \\ \text { Virtuous } & \text { Virtuous } \\ \text { Virtuous } & \text { Virtuous }\end{array}$

Virtuous
Virtuous
EG-Lopsided
Virtuous
Vicious
HD-Lopsided
Vicious
HD-Lopsided
HD-Lopsided
Virtuous
Virtuous

Virtuous

HD-Lopsided

HD-Lopsided

Virtuous

Vicious

Virtuous

Vicious

Vicious

HD-Lopsided

Virtuous

HD-Lopsided

Virtuous

Latin America

\begin{tabular}{lcccc} 
Argentina & Virtuous & HD-Lopsided & HD-Lopsided & HD-Lopsided \\
Bolivia & Vicious & Vicious & Vicious & Vicious \\
\hline
\end{tabular}




\begin{tabular}{|c|c|c|c|c|}
\hline & $1960-1970$ & $1970-1980$ & 1980-1990 & 1990-2001 \\
\hline Brazil & Virtuous & Virtuous & HD-Lopsided & HD-Lopsided \\
\hline Chile & Virtuous & HD-Lopsided & HD-Lopsided & Virtuous \\
\hline Colombia & Virtuous & Virtuous & HD-Lopsided & HD-Lopsided \\
\hline Costa Rica & Virtuous & Virtuous & HD-Lopsided & HD-Lopsided \\
\hline Dominican Republic & Virtuous & Virtuous & HD-Lopsided & Virtuous \\
\hline Ecuador & HD-Lopsided & Virtuous & HD-Lopsided & HD-Lopsided \\
\hline El Salvador & Virtuous & Vicious & Vicious & HD-Lopsided \\
\hline Guatemala & Virtuous & EG-Lopsided & Vicious & HD-Lopsided \\
\hline Haiti & Vicious & EG-Lopsided & Vicious & Vicious \\
\hline Honduras & Vicious & Vicious & HD-Lopsided & HD-Lopsided \\
\hline Jamaica & Virtuous & HD-Lopsided & HD-Lopsided & HD-Lopsided \\
\hline Mexico & Virtuous & Virtuous & HD-Lopsided & HD-Lopsided \\
\hline Nicaragua & Virtuous & HD-Lopsided & Vicious & HD-Lopsided \\
\hline Panama & Virtuous & HD-Lopsided & HD-Lopsided & HD-Lopsided \\
\hline Paraguay & Virtuous & Virtuous & HD-Lopsided & HD-Lopsided \\
\hline Peru & Virtuous & Vicious & HD-Lopsided & HD-Lopsided \\
\hline Trinidad and Tobago & Virtuous & Virtuous & HD-Lopsided & HD-Lopsided \\
\hline Uruguay & HD-Lopsided & Virtuous & HD-Lopsided & HD-Lopsided \\
\hline Venezuela, RB & HD-Lopsided & HD-Lopsided & HD-Lopsided & HD-Lopsided \\
\hline \multicolumn{5}{|l|}{ South Asia } \\
\hline Bangladesh & Vicious & Vicious & Vicious & Vicious \\
\hline India & Vicious & Vicious & EG-Lopsided & Vicious \\
\hline Nepal & Vicious & Vicious & Vicious & Vicious \\
\hline Pakistan & EG-Lopsided & Vicious & Vicious & Vicious \\
\hline Sri Lanka & Virtuous & Virtuous & HD-Lopsided & HD-Lopsided \\
\hline
\end{tabular}

\section{COUNTRY STUDIES}

In these studies, we have focused particularly on the strengths and weaknesses of the main links in the chains relating EG to HD and HD to EG. In the first case (EG to HD) the links determining how effectively EG translates into HD include the determinants of public resources to support HD (i.e. the ratio of total government expenditure to GDP, the allocation of government expenditure to the social sectors and the priority ratio, or the proportion of social sector expenditures going to HD-supportive activities), the distribution of income among households, as well as the relative position of women, especially with respect to education, which helps to explain household expenditure patterns as well as health outcomes . In the second case (HD to EG), in addition to the education and skills of the workforce, the links determining how effectively HD produces EG include savings and investment rates, foreign direct investment (FDI) and economic policies such as towards competition and technology transfer (see Ranis et al., 2000 for further elucidation of these links and some empirical evidence on them for all developing countries).

In order to assess our country performances with respect to these and other aspects we introduce a 'comparator' which consists of the average achievement on any variable for all 
developing countries. Hence in our analysis we regard performance of any country 'above the comparator' as relatively good, and 'below the comparator' as relatively poor. ${ }^{3}$

\section{III.I. From Vicious to Virtuous Development: China and Vietnam.}

\section{China:}

Introduction

China is a country that moved from a vicious cycle position which obtained before the 1950 s to an HD-lopsided one in the 1960s, and then to a sustained virtuous cycle. At the same time, it saw massive political changes, with the Communist revolution of 1949, Mao's Great Leap Forward and the Cultural Revolution of the 1960s, followed by limited political liberalization and some reduction in economic interventions. Before the Communists came to power in 1949, China was beset by foreign threats, civil war, malnutrition and poverty and both HD and EG were very poor. The Communist revolution saw a rapid improvement in HD, and there was also substantial economic growth, interrupted in the 1960s by the Great Leap Forward and then the Cultural Revolution, consequently putting China into the HDlopsided category. From 1979 onwards there followed a series of economic reforms and growth accelerated, supported by the high levels of HD that had been achieved earlier. From then on, China entered and remained in a virtuous cycle.

\section{From vicious cycle to HD- lopsided, 1950-1970}

Health and education stagnated in the pre-Communist era and the basic needs of the people were neglected. In 1945, life expectancy was only 30.5 years with infant mortality at 265 per 1000 (CHDR 1999). While education was highly valued by the elite, there were few public schools and only a small proportion of the population could afford time or money for schooling. As a result, by 1949 over $80 \%$ of the total population was illiterate and only 1 in 4 children were enrolled in primary school (CHDR 1999). Land was distributed highly unequally, with $70-80 \%$ of the land owned by just $10 \%$ of the landlords (China Ministry of Agriculture 1989). Recurrent financial problems turned many farmers into landless tenants in a feudal and exploitative system. Both EG and HD stagnated.

After the 1949 revolution considerable emphasis was placed both on improving HD and developing the economy. The feudal agrarian system was abolished and communes and collective farming introduced, greatly improving income distribution and reducing poverty. In addition, state-owned communes and industries maintained a relatively equal rate of pay for most workers. The government gave women equal rights in ownership and career advancement with a consequent rise in female participation.

The Communist Party's first two Five-Year plans, of 1952 and 1957, markedly increased national expenditures on health and education. The government instituted a comprehensive health care system, emphasizing prevention. National expenditure on health care increased 11-fold from 1950 to 1960 . Some infectious diseases were eradicated; for example, smallpox was eliminated in 1961, a decade earlier than in most other countries. Hospitals and health personnel also expanded: from 85,000 hospital beds and 541,000 healthcare givers in 1949 these had risen to over 1 million and over 1.8 million, respectively, by 1965. In addition, a system of 'barefoot doctors' evolved -- village residents with elementary medical training who became the local healthcare providers -- at its height covering over $85 \%$ of villages (CHDR 1997). Sanitation standards also improved: in 1949, less than $10 \%$ of the population had access to clean water; by 1979 , over $50 \%$ of the urban population and over $40 \%$ of the rural population had access (Jamison, 1984).

\footnotetext{
${ }^{3}$ Again these averages are weighted by country population size.
} 


\section{China Figures}
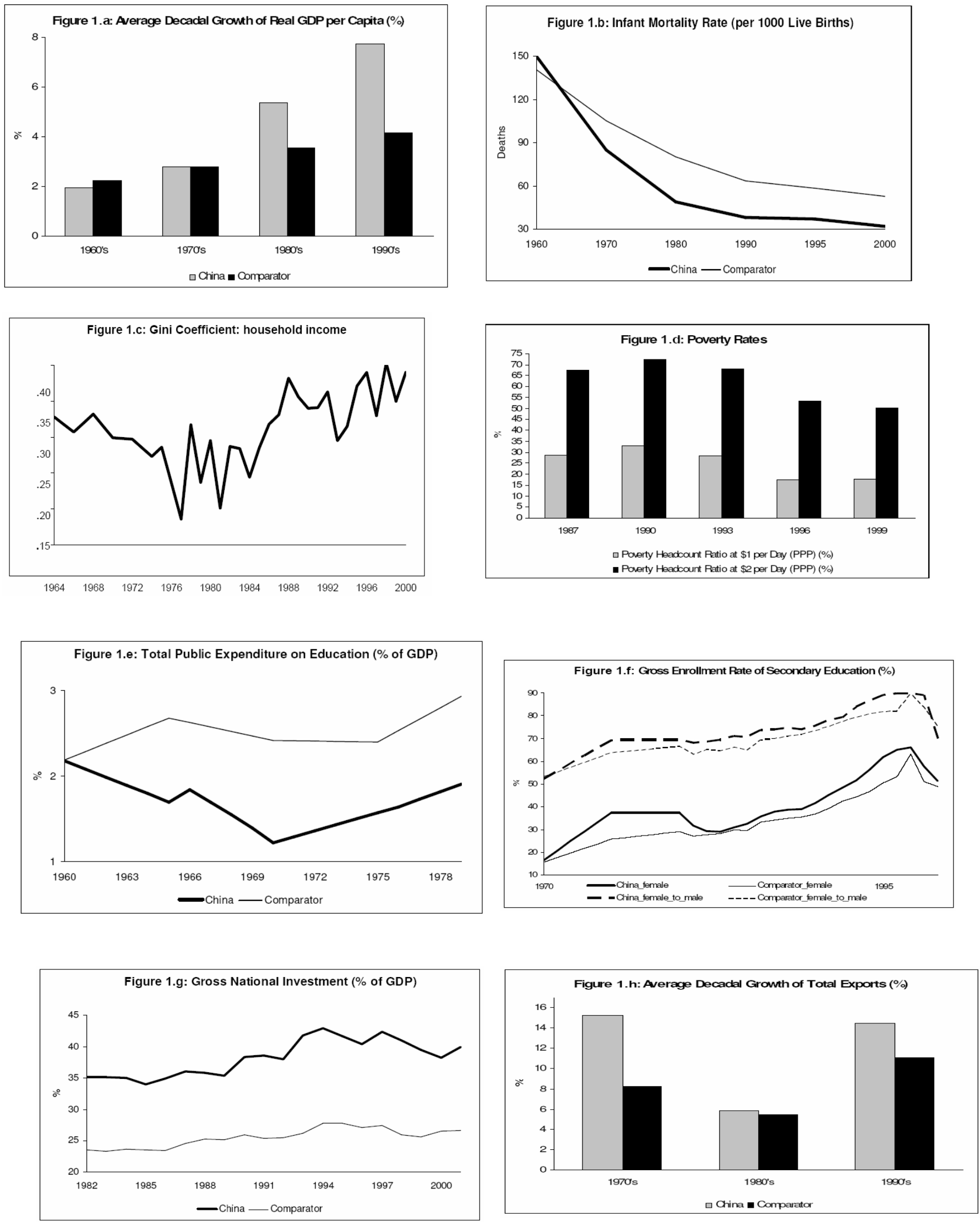
The government also put great emphasis on improving education to tackle the country's high illiteracy rate. The number of primary schools more than doubled between 1949 and 1979 and the number of secondary schools rose from 4,298 in 1949 to over 162,000 in 1978 . Despite apparently low government expenditure relative to GDP (Figure 1e), significant increases in school enrollment resulted, with the biggest improvements occurring among the rural and minority populations. ${ }^{4}$ Overall, the enrollment rate of primary school-age children rose from 25\% in 1949 to over 100\% by 1960, with about one-fifth going to secondary schools (CHDR 1999).

Heavy investment in irrigation led to an acceleration in agricultural production, to 5.3\% p.a. 1953-1957. For 1952-1956, there was also very high growth in industrial output (13.5\% p.a.) and GDP grew at a rate of $8.4 \%$ p.a. over those years. Indeed, China was clearly briefly in a virtuous cycle between 1950 and 1956. However, the government's achievements in both HD and EG were then disrupted by the Great Leap Forward (1957-1960) and the Cultural Revolution (1966-1970). Failure of the former led to the disastrous famine of 1958-1961 in which perhaps as many as 30 million people died (Gulati et al., 2005).

The Cultural Revolution caused another setback in the 1960s. This particularly affected the educational system. Most schools were shut down and almost 18 million young people - virtually a whole generation - was sent to the countryside.

Government expenditure on education dropped from 2.18\% of GDP in 1960 to 1.22\% in 1970. Primary enrollment rates which had reached over 100\% fell to 89\% by 1965 . Data for secondary enrollment in the mid-1960s, the height of the Cultural Revolution, are not available. Tertiary education, which had risen from 2.2 per 1000 of the population in 1949 to 12.3 by 1962, fell sharply to just 0.6 in 1965, recovering to 5.4 by 1970 . An entire generation of intellectuals and technicians was lost in the chaos of the late 1960s (CHDR 1999). Mao officially called off the Cultural Revolution in 1969, although its repercussions were felt for at least another decade.

However, one of the few positive aspects of the Cultural Revolution was its weakening of deep-rooted patriarchal traditions. Mao mobilized women effectively, increasing their participation to $43 \%$ of the labor force (CHDR 1990). Women worked alongside males as Red Guards, factory workers, teachers, and sales clerks, among other positions. The elevation of female social status, on top of the improvements in female property rights and education that occurred after 1950, were major factors that contributed to improvements in HD.

Investment rates were very high in the 1950s, but fell sharply with the Great Leap Forward, recovering later. Growth in per capita income was high in the early 1950s, but negative over the Great Leap Forward era (1957-1962), recovering subsequently, and was somewhat above the comparator for the 1960s as a whole, despite the setbacks of both the Great Leap Forward and the Cultural Revolution.

HD achievements are shown by the improvements in life expectancy, infant mortality and literacy rates. Life expectancy more than doubled, from 30.5 in 1945 to 63 in 1970, despite a decline during the years of the Great Famine. Infant mortality rates followed a similar trend, falling from 252 deaths per 1000 live births in 1950 to 85 by 1970 . Adult literacy reached $53 \%$ by 1970 and the female/male gap narrowed.

\footnotetext{
${ }^{4}$ Prior to 1949 , minorities accounted for $6 \%$ of the total population, but only comprised $2.2 \%$ of the primary school population. By 1956, the minority enrollment rate had risen to $5 \%$ of the total enrollment.
} 
Income distribution was relatively equal, particularly in comparison with the prerevolutionary situation, with a Gini of around 0.3 during this period.

In summary, this era, taken as a whole, showed HD-lopsided performance, with major improvements in HD, while economic growth, which was impressive in the early 1950s, was severely disrupted by the Great Leap Forward and the Cultural Revolution.

\section{From HD-lopsided to virtuous performance: 1970 s and beyond}

There was a major resurgence in both HD and EG, after the Cultural Revolution ended and following the introduction of economic reforms at the end of the 1970s.

Reforms were gradually introduced after 1978, first focusing on agriculture, where a household responsibility system was introduced, with an increasing role for individual incentives and a reformed price system. Following the dramatic success of the agricultural reforms, industrial reforms followed in the mid-1980s, with an increased role for the market and private enterprise.

Progress in HD continued. Gross enrollment in secondary education accelerated, and the female/ male ratio rose from 52\% in 1970 to 69\% in 1980 (Figure 1f). Adult literacy reached $68 \%$ by 1980 . This good HD progress was accompanied by a continued rise in savings and investment rates (Figure 1g): the investment rate rose to $29 \%$ by $1970,35 \%$ by 1980 and $36 \%$ by 2000 . Foreign capital inflows, previously insignificant, spiraled in the 1980s. By the 1990s, there was a huge inflow of FDI, amounting to over 6\% of GDP in 1992 and remaining at over 4\% for the rest of the decade.

The skills and knowledge gained through primary schooling contributed to raising workers' efficiency, with labor productivity rising three and half times between 1949 and 1978. Additionally, secondary and tertiary schooling provided managerial and technical training, leading to more R\&D and technological improvements. After the reforms initiated in 1978, the annual increase in scientific and technological personnel quintupled to more than 800,000 and in 1986 China started a high tech program and a National Natural Science Fund with the express purpose of catching up with developed countries. Expenditure on R \& D rose rapidly, particularly in the 1990s, while other reforms improved the links with economic innovation.

Structural transformation of the economy involving an increasing role for industry, which had started in the 1950s, accelerated in the 1980s. Industrial output accounted for $24 \%$ of GDP in $1952-56$, rose to $34 \%$ by $1976-80$, and to over $50 \%$ by 2000. Export growth was very rapid, at 15\%, 5\%, 14\% over the 1970s, 1980s and 1990s, respectively (Figure 1h). Exports grew from 1.8\% of GDP in 1970 to $7.6 \%$ in 1980 and to $26 \%$ in 2000 . The increasing sophistication of the economy, made possible by the high availability of skills, is indicated by the change in the composition of exports, with primary exports falling from $46 \%$ of total exports in 1984 to $11.6 \%$ in 2000, while high tech exports rose from $2.0 \%$ in 1984 to $16.7 \%$ in 2000 , double the rate of the comparator. Such rapid structural transformation of the economy was only possible because of the high levels of education.

The combination of improving HD, high savings and investment rates, and successive policy reforms led to an acceleration of EG from the 1970s onward. The per capita growth rate for the 1970 s was over $4 \%$ p.a.; for $1978-1984$ it was $9.8 \%$ p.a. and it remained above $8 \%$ p.a. over the following decades. In the post-reform period 
taken as a whole, 1978-2002, the annual growth rate was $8.2 \%$ p.a., compared with $5.4 \%$ p.a. for the pre-reform period of 1952-1977.

Such rapid economic growth in turn contributed to further improvements in HD. Moreover, the proportion of resources devoted to education increased, amounting to $3.7 \%$ of GDP by 2000 , compared with $3.1 \%$ in 1980 . However, income distribution deteriorated significantly during the 1980s and 1990s, the Gini coefficient increasing from 0.21 in 1978 to 0.46 in 2000 (Figure 1c). Nonetheless because of the rapid growth, poverty declined during this period. The $\$ 2$ a day poverty rate fell from over $65 \%$ in 1987 to $50 \%$ in 1999 , while the $\$ 1$ a day rate fell from $28 \%$ to $18 \%$ (Figure 1d). All indicators of HD showed continued improvement during the three decades. The adult literacy rate rose from 53\% in 1980 to $91 \%$ in 2000 and the gap between women and men narrowed sharply. Life expectancy rose from 63 years in 1970 to 70 in 2000; and the infant mortality rate fell from 85 to 32.

\section{Conclusion}

The Chinese case shows how a country can transform itself from a vicious to a virtuous cycle situation. After the Communist revolution, China placed emphasis on improving HD and technical change, especially in agriculture. While progress on EG and HD was sharply interrupted by the Great Leap Forward and the Cultural Revolution, once these were over and economic reforms were introduced China was able to make use of its high levels of human development to generate rapid growth, through a combination of high savings and investment and judicious policy reforms. The China case demonstrates how a virtuous cycle is self-reinforcing, with higher growth providing resources for additional HD, and this in turn assisting economic growth in a synergistic fashion, a pattern which has been sustained in China over several decades. However, the unusual political system underlying this dramatic social and economic transformation may make it unlikely to be replicated in many other countries.

\section{Vietnam:}

\section{Introduction}

Vietnam is another example of a country that moved successfully from a vicious to a virtuous cycle, despite political upheavals and a major conflict. In the colonial period both economic and social development were neglected. Independence in 1954 led to the division of the country into a Communist-controlled North and a US-dominated South. Over the next decade, both North and South promoted human development, albeit seriously handicapped by war. After the Vietnam War ended in 1975, a united Vietnam moved into an HD-lopsided state, in which the ruling Communist government continued to pursue policies that strengthened health and education levels. However, economic growth did less well. After a period of hyperinflation and stagnation in the mid-1980s, the government adopted a set of promarket economic reforms which led to the transformation of the economy, with rapid industrialization made possible by the good HD levels already attained. From then on, Vietnam moved into a virtuous cycle.

\section{From vicious to HD-lopsided, 1950s-1970s}

Before the 1950s, poverty was pervasive and access to education and healthcare was limited to a few members of the upper class (Glewwe, 1998). Colonial powers dominated the economic and political spheres, paying little attention to the 
condition of the local population. Following war and subsequent victory against France, the North and South were divided at the $17^{\text {th }}$ parallel in 1954.

The rival regimes in Hanoi and Saigon, possibly acting in competition with each other, both promoted HD-oriented polices. A comprehensive primary education program reached both rural and urban populations. As a result, by 1970, the overall literacy rate for the two parts of Vietnam was at an impressively high level of 83\%, with a 75\% female literacy rate, both significantly above levels in other developing countries at that time (ECRP 1998). Just before reunification in 1975, the gross enrollment rate for girls in primary school was at 108\%, slightly above that of boys.

After 1975, the Communist government substantially expanded technical and vocational education. The number of students in institutions of higher learning increased rapidly, from approximately 50,000 (29,000 in the North and 20,800 in the South) in 1964 to a total of 150,000 in 1980 (VSD 004), of which around 23\% were female. Secondary education continued to expand and achieved an enrollment rate of $42 \%$ by 1980 , with a female/male ratio at $95 \%$, well above the comparator (SDSRV 1991).

A strong commitment to basic health care was evident over the whole period, with special attention to children, resulting in much improved mortality rates and life expectancy (Figure 2b). After reunification, health services were provided free of charge throughout the country's provinces, districts, and communes, extending down to the brigade level. Healthcare coverage was extensive and mostly equitable, despite some inefficiencies. The ratio of physicians to population was 1 per 1,000 in 1979, compared with 1 per 180,000 in 1945. The infant mortality rate went from 70 in 1960 to 44 in 1980 and life expectancy, which had been just 34 in 1945, reached 63 years by 1979 (SIDA 1994).

Thus, after the end of the war the socialist regime in Vietnam continue to promote HD, but economic growth remained low. From 1965 to 1980 per capita income growth was $0.6 \%$ p.a. compared with $3 \%$ p.a. for all developing countries. In summary, there was a shift from a vicious cycle pattern of development in the preindependence period and immediately thereafter, to an HD-lopsided one during the 1970s.

\section{0s to 2000: transition to a virtuous cycle}

The improvements in education and health provided a strong platform for the economy to grow following the drastic 'Doi Moi' economic reforms. A largely educated work-force was consequently available to support the reforms introduced in the 1980s and 1990s. By the early 1980s, serious weaknesses became evident in the dominant central planning model (Fforde, 1997), when economic growth stagnated, inflation rose rapidly, chronic shortages in basic consumption goods appeared, and tax revenues declined. The situation was exacerbated by the drying up of aid from the former Soviet Union, on which Vietnam had been heavily dependent.

In the early 1980s, the state made various attempts to rectify the situation with the help of some micro-level market reforms, such as introducing the 'three-plan system' for state-owned-enterprises starting in 1979, and the authorization of 'output contracts' (khoan san pham) in agriculture (Beresford, 1989), which gave producers the freedom to buy and sell above their quota output. Yet, these microeconomic reforms appeared insufficient. Although economic growth picked up slightly, persistent macroeconomic instability prevailed, with inflation well into triple digits (Boothroyd, 2000). Consequently, more radical macro reforms were introduced. 


\section{Vietnam Figures}
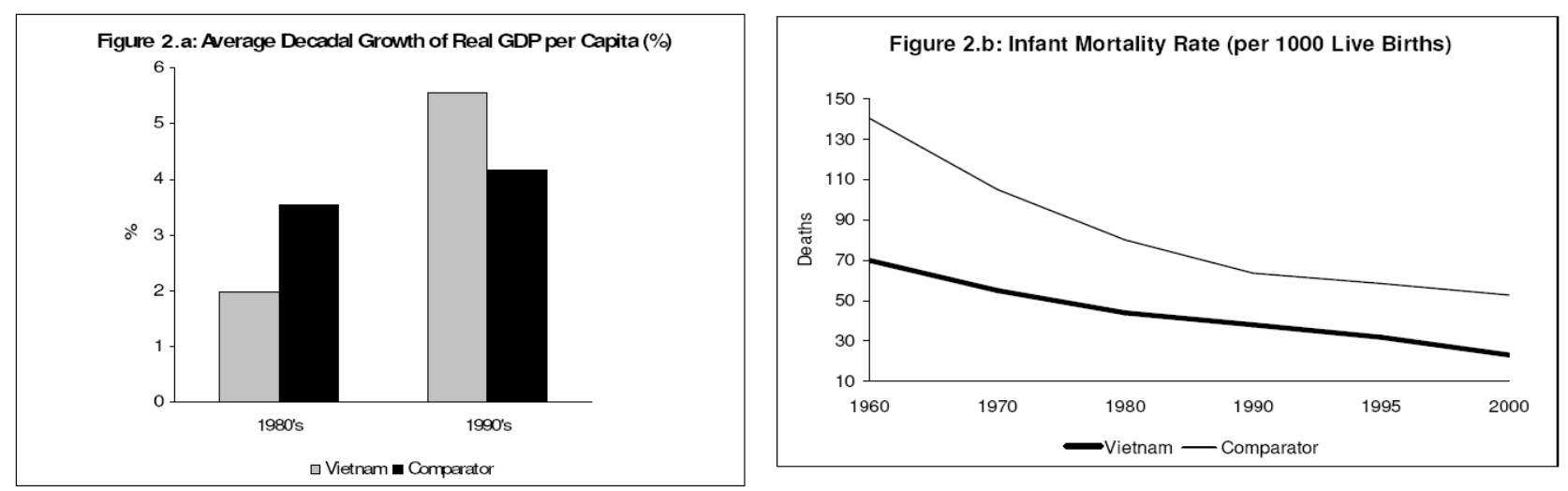

Figure 2.c: Gini coefficient: household income

\section{$1996 \quad 0.377$}
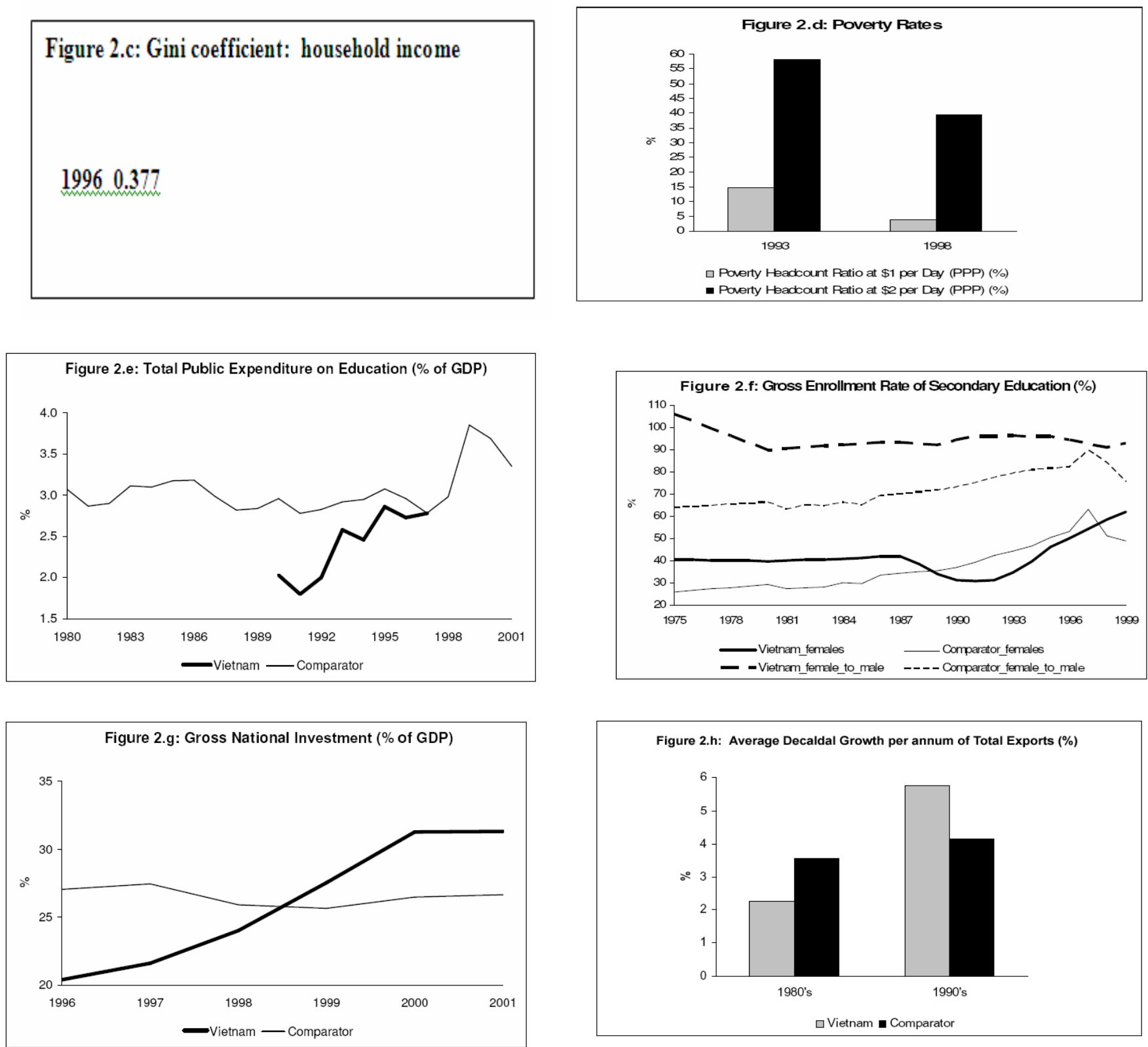

Figure 2.h: Average Decaldal Growth per annum of Total Exports (\%)

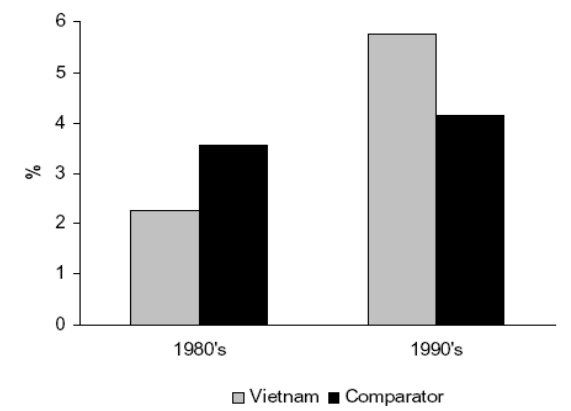


The reform process had two major aspects, namely a gradual move away from central planning domestically and an opening up to the rest of the world via an 'open door policy.' In 2000, policies were also introduced to encourage medium and smallscale enterprises. A further stimulus to growth was the spillover of capital and entrepreneurial energy from Vietnam's dynamic neighbors, particularly China.

As a consequence, Vietnam became one of the fastest-growing economies in the world, averaging almost 6\% per capita GDP growth in the 1990s, compared with $2.3 \%$ p.a. in the 1980s (Figure 2a). The inflation rate, which stood at an annual rate of over 300\% in 1987, fell dramatically to less than 10\% in the mid-1990s (VSD 2004). At the same time, investment grew three-fold (fuelled by FDI, which fluctuated between $3 \%$ and $12 \%$ of GDP in the 1990s ) while domestic savings quintupled, i.e. gross domestic savings reached $27 \%$ of GDP by 2000 , and the gross investment rate 31\% (Figure 2g). Agricultural production doubled, transforming Vietnam from a net food importer to the world's second-largest exporter of rice in the 1980s and the largest by the end of the century (US Department of State website, Background Note: Vietnam). However, a more significant transformation came from the growth of the industrial sector. As a proportion of total output, industry grew from 29\% in 1986 to $37 \%$ in 2000. New services, such as insurance, auditing and consultancies, expanded rapidly, supported by technology transfers.

With the help of the higher human development levels achieved in earlier decades, the Doi Moi reforms had remarkable success. Foreign trade increased significantly. Total exports which were $6.6 \%$ of GDP in 1986 increased dramatically to reach 55\% in 2000 (Figure 2h). Primary exports which were 98\% of the total in the early 1970 s fell to $53 \%$ by 2001 . Per capita income grew by $2.3 \%$ in the 1980 s and accelerated to $5.8 \%$ p.a. in the 1990 s (Figure 2a) and almost $8 \%$ in the early $21^{\text {st }}$ century. The Asian financial crisis had only a minor impact on Vietnam.

The economic growth experienced in the 1990s, in spite of some worsening in income distribution, contributed to further improvements in human development. The Gini was 0.38 in 1996. Poverty incidence, based on the World Bank poverty line of $\$ 2$ per capita per day, dropped from over $70 \%$ in the mid-1980s to around $58 \%$ in 1993 and further to an estimated 32\% in 2001, while the \$1 per capita poverty rate was just 3.8\% by 1998 (Figure2d). The tax/GDP ratio rose to $17 \%$ by 2000, and the government funneled increasing resources into education. Secondary school enrollment rose from $33 \%$ in 1990 to $75 \%$ in 2003 . Public education expenditure as a percentage of GDP rose from $2.0 \%$ in 1990 to $2.7 \%$ in 1996, and, as a percentage of government expenditure, from 16\% in 1990 to 33\% in 1996. As a result, Vietnam maintained a high level of literacy, reaching 94\% in 2003 (World Bank). Public expenditures on health, which fell to a low of $0.24 \%$ of GDP in 1985, increased to 1.3\% by 2000 (World Bank 1992; UNDP 2003). In contrast, military expenditure, which peaked in the late 1980s, decreased from 7.1\% of the GDP in 1988 to $2.6 \%$ of the GDP in 1994.

Improvements in HD continued. The adult literacy rate was $93.1 \%$ in 2001, while life expectancy was 67.8 (World Bank). The infant mortality rate fell from 44 in 1980 to 23 in 2000 (Figure 2b). This clearly shows that Vietnam has become a virtuous cycle country case, with human development and economic growth fueling one another.

\section{Conclusion}

Vietnam represents another case of a country moving from a vicious to a virtuous cycle via two successive transformations, first into an HD-lopsided cycle and then 
into a virtuous cycle. As with China, there is a complex underlying political economy dimension to these changes - with the Communist regime emphasizing HD, and thus laying the groundwork for subsequent EG. Like China, progress was achieved despite some severe shocks, in this case the Vietnam War. Again, like China, a closed economy and central planning gave way to market-oriented and open economy reforms favoring growth, undoubtedly influenced by the experience of China.

\section{2. Successful transition from HD-lopsided to virtuous: Chile}

\section{Introduction}

Chile has had a very long history of giving priority to HD. In 1960, life expectancy, infant mortality rates and literacy were far higher than among developing countries generally. Over the decades $1960-2000$ a turbulent political history saw a democratic socialist regime displaced in 1973 by Pinochet's military dictatorship which lasted twenty years; democracy was reintroduced in the early 1990s. Despite these political upheavals, HD progress was sustained over the four decades. However, growth, which had been good in the 1960s, lapsed in the following two decades, putting Chile into the HD-lopsided category. Growth then accelerated in the 1990s and Chile entered the virtuous cycle.

Chile's success on HD over these decades was due to a varying combination of high social expenditures and favorable priority ratios. In the 1960s, success was expenditure led. The subsequent military regime, in contrast, further improved the priority ratio while cutting expenditure. Total expenditure rose again in the later democratic era, partly due to a reduction in military expenditure. Despite good HD, economic growth remained mostly poor in the 1970s and 1980s, initially due to political turbulence and later due to financial crises and strongly deflationary policies.

\section{HD achievements over four decades}

It is remarkable that HD retained its priority throughout - from a socialist democratic regime, through military dictatorship, to a return to democracy. In part this is a reflection of a deep-seated historical culture and policies favoring HD, dating back at least to the beginning of the $20^{\text {th }}$ century (Astorga, Berges and FitzGerald 2005).

In the 1960s, HD was promoted by increasing government expenditure. In 1960 the government expenditure ratio was low at 9\%, but this rose rapidly in the 1960s, peaking at over 15\% in the early 1970s. The share going to education was high and rising over this period, ranging from 27\% in 1960 to 38\% in 1970 (moving from below to substantially above the comparator). The share of GDP going to education rose over the same period, reaching 4.8\% in GDP in 1970, well above the comparator (Figure 3e).

However, during the military dictatorship, the government expenditure ratio fell sharply, particularly in the 1980s, while the share going to education fell from $38 \%$ in 1970 to $26 \%$ in 1990 . Consequently, education expenditure as a share of GDP fell in the 1980s and was only $2.5 \%$ in 1990 (well below the comparator). However, at the same time the priority ratio improved sharply. Primary education went from $43.5 \%$ in 1980 to $61.8 \%$ in 1990 , as government support for tertiary education was cut sharply. 
Chile Figures

Public expenditure on health as a percentage of GDP ranged between two and three percent over the decades (though data here are weak), showing no particular trend. The military regime placed additional emphasis on preventative health. It also, privatized much health care.

In the 1990s, under the new, democratic regime, the expenditure ratio rose slightly to over $11 \%$. Meanwhile, the share going to military expenditure fell from $38 \%$ in 1990 to $25 \%$ in 1996 , education rose from $25.7 \%$ to $35.4 \%$, and health from $20.5 \%$ to $24.2 \%$. Education expenditure as a percentage of GDP rose from $2.5 \%$ in 1990 to $3.9 \%$ in 2000 , once again above the comparator. The priority ratio in education also continued to improve.

Income distribution historically has been quite unequal in Chile, due in part to very unequal land distribution and the concentration of output on copper. It became even more unequal over time, with the Gini rising sharply from 0.46 in 1974 to 0.55 in 1990 and 0.58 in 2000 (Figure 3c). Poverty was relatively high in the 1980s, but declined in the 1990s, in spite of the unfavorable income distribution, due to the high growth rate (Figure 3d).

Gross enrollment rates in primary education exceeded $100 \%$ for most of the period, and, exceptionally for developing countries, the female rate was almost as high as the male. Secondary enrollment rates were consistently above the comparator and female enrollments exceeded male (Figure 3f). Adult literacy rates rose steadily to over $95 \%$ by 2000 and the small female/male gap was virtually eliminated by 2000 . Both life expectancy and infant mortality rates improved markedly and remained much better than the comparator (Figure 3b). By 2000 the latter was just 10, compared with 53 for the comparator.

\section{Human development supports economic growth: the 1990s}

In the 1970s and 1980s, growth was poor, despite the good HD. In the 1970s this was due to the major economic upheaval caused by the military take-over. In the 1980s financial problems and strongly deflationary policies were responsible. While FDI was low in the 1970s, and sometimes even negative, it became consistently positive in the 1980s. Gross investment as a whole was well below the comparator for the 1980s, falling sharply in the middle of the decade, and recovering thereafter (Figure 3g).

However, in the 1990s, the strong HD combined with rising investment rates and rising net inflows of FDI to increase EG. Gross national savings were only $12 \%$ of GDP in 1986 but rose thereafter to just over 20\% throughout the 1990s. Net inflows of FDI also jumped from less than 1\% of GDP in 1980 to over 5\% between 1994 and 2000. The market reforms of the 1980s - particularly depreciating exchange rates and the introduction of policies that encouraged entrepreneurial activity provided the conditions for the flourishing of export diversification. However, output expansion was largely based on the diversification of agriculture, with little change in sectoral composition. Nonetheless, exports rose rapidly, doubling as a proportion of GDP between the early 1970s and 2000 (Figure 3h). This expansion was mainly based on new agricultural products, such as fruits, fish, wine, methanol, as well as an expansion of tourism. Copper declined from 74\% of exports in 1973 to 38\% in 1999. High-tech exports continued to be low, as did textiles. 


\section{Conclusion}

The Chilean case shows how a country can graduate into a virtuous cycle following an HD-lopsided position. Chile retained a strong commitment to HD throughout the decades, irrespective of political regime, although different regimes promoted HD in different ways. For two decades there was no growth pay-off to the improved HD because of political turbulence and excessively deflationary policies. In the 1990s, however, economic incentives and good HD came together to generate good economic growth and a virtuous development cycle. In principle, this good outcome should be sustained, with growth helping to promote HD further and this in turn helping to sustain growth. However, for the future two questions are outstanding: first, whether the resource pattern of present growth - heavily focused on agricultural diversification and tourism - has the potential to sustain long-term growth; and secondly, whether the high and rising inequality can be reversed. With its very strong $\mathrm{HD}$, however, Chile is in a good position to exploit alternative economic opportunities if her current economic growth pattern should come up against constraints.

\section{3. From vicious to HD-lop-sided: Turkey}

\section{Introduction}

Turkey followed a vicious cycle pattern in the 1970s and 1980s, making a transition into HD-lopsided development in the 1990s. The country was governed by the military for most of the 1960s and 1970s. ${ }^{5}$ However, democratic institutions were strengthened towards the end of this period - a change which has been attributed in large part to Turkey's desire to join the European Union. This change appears to have had an important effect on both social and economic policies.

\section{The vicious cycle period: 1970s and 1980s}

The early vicious development cycle was associated with high military expenditures, low social expenditures, high rates of population growth, and poor income distribution which dragged down HD performance; this in turn reduced economic growth.

Expenditure on education remained low (2\% or less as a proportion of GDP) until 1990, largely due to a low expenditure ratio. Nonetheless enrollment in primary education and the female/male ratio exceeded that of the comparator, while secondary enrollment was very similar to the comparator, but with a worse female/male ratio (Figure 4f). Life expectancy and literacy rates were somewhat better than the comparator, but infant mortality and under five mortality were worse during the 1970s and 1980s.

Economic policies in the 1960s and 1970s were highly interventionist and protectionist and supported a large public sector. Remittances made a major contribution to the economy's foreign exchange needs during this decade. However, large budget deficits were associated with high inflation. These economic policies resulted in rapid industrialization but were accompanied by periodic financial crises and low investment rates, e.g. gross investment fell from 18\% in 1974 to $14 \%$ in 1979 (Figure 4g). The export ratio was just $5 \%$ by the end of the 1970 s compared with $13.5 \%$ for the comparator. Growth in per capita income was $1.8 \%$ p.a. on average during the 1970s (Figure 4a).

\footnotetext{
${ }^{5}$ Hale, 1981; Utkulu, 2001.
} 


\section{Turkey Figures}
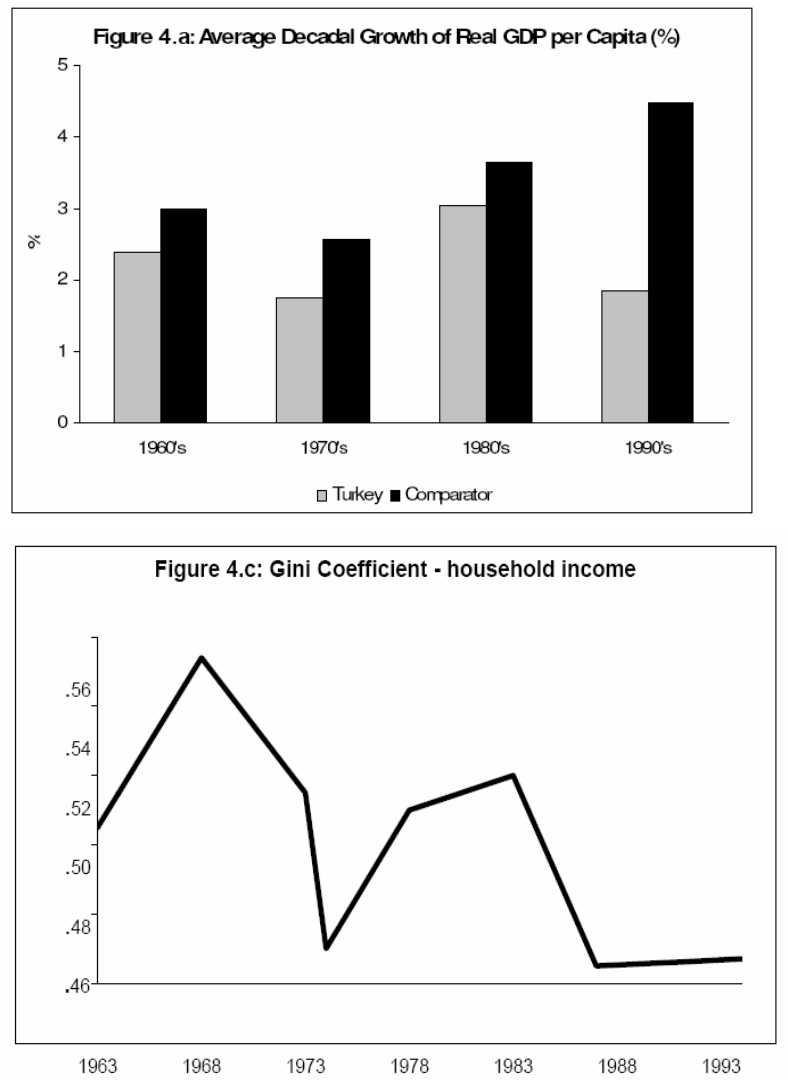

Figure 4.e: Total Public Expenditure on Education (\% of GDP)
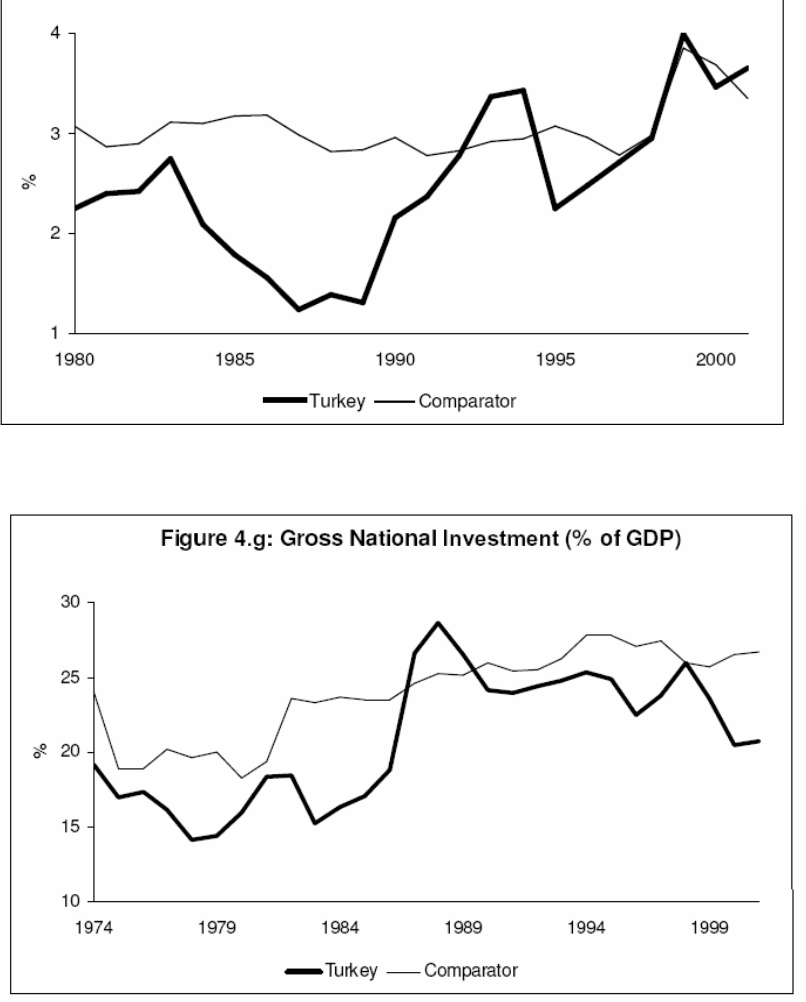
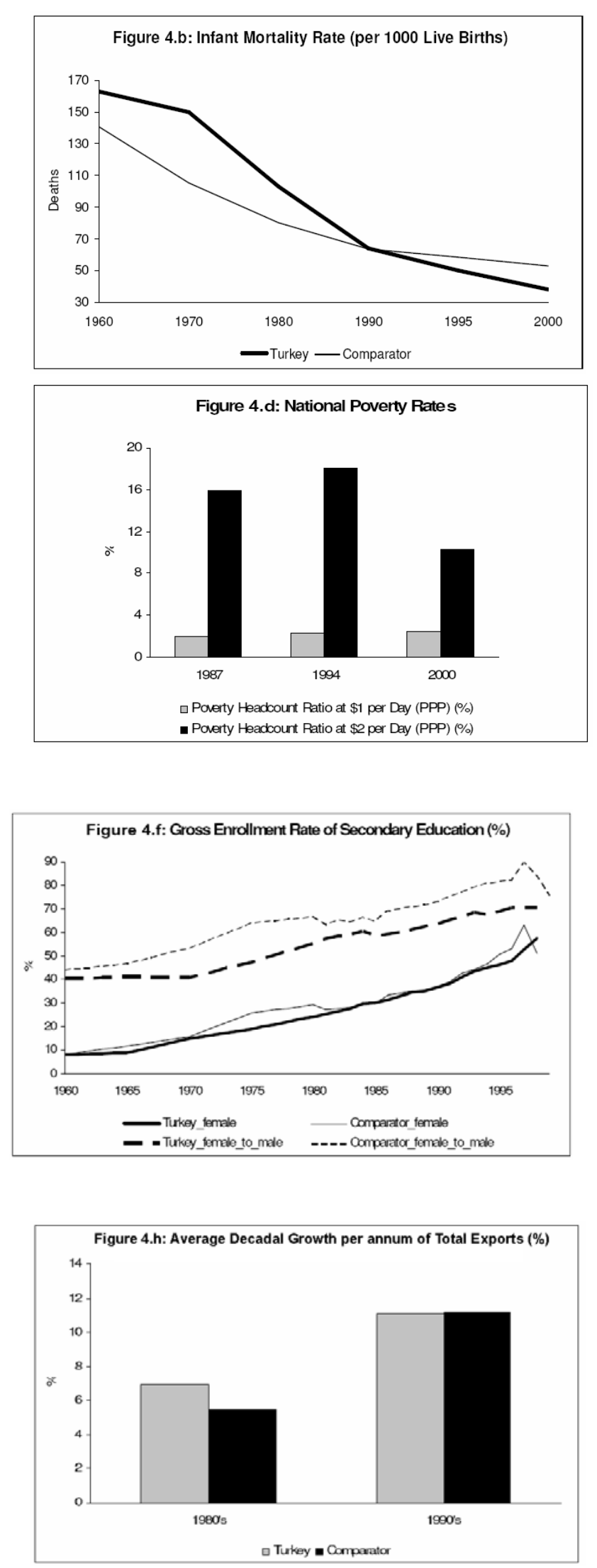
Following an acute debt and financial crisis at the end of the 1970s, the government introduced major liberalizing reforms. ${ }^{6}$ These followed the typical agenda, moving from an interventionist import substitution strategy towards export orientation, with trade liberalization, privatization and financial reforms. Exchange rate policy was also made more flexible with frequent devaluations. Import licensing was abolished. The gross investment ratio rose from $18 \%$ in 1980 to $24 \%$ in 1990 , but foreign direct investment remained low throughout the 1980s. The export ratio rose to $15 \%$ by the end of the 1980s, accompanied by export diversification, as indicated by a rising share of textiles. Nonetheless, while the growth rate rose to $2.9 \%$ p.a. in the 1980s, it fluctuated wildly and remained below the comparator; Turkey remained in the vicious cycle category (Figure 4a).

\section{From a vicious cycle to improved Human Development in the 1990s}

The transition from poor to good HD was achieved through an increase in social expenditures, higher female to male primary enrollments and an improvement in the distribution of income.

Social expenditures rose significantly in the 1990s, mainly due to a dramatic rise in tax revenues and expenditures relative to GDP, and partly to a modest reduction in military expenditure as a proportion of the total, both associated with the transition to civilian governments. Between 1970 and 2000, tax revenues increased, from $10 \%$ to about $22 \%$ of GDP, associated with a broadening of the tax base, particularly as a result of the introduction of a value added tax and a reduction of tax evasion. During the 1990s, military expenditure as a percentage of central government expenditure decreased somewhat, from $39.4 \%$ to $35.5 \%$, while education expenditure rose from $19.7 \%$ to $24.6 \%$. Education expenditure as a proportion of GDP rose from $2.2 \%$ (1990) to 3.5\% (2000), approaching the comparator (Figure 4e).

In the 1990 s, over $75 \%$ of public expenditure on education was spent on primary and secondary level schooling, which represents a fairly good social priority ratio. There was some shift of funds towards tertiary education at the expense of primary education after 1995, by which time gross primary and secondary school enrollment rates had reached $100 \%$ and $60 \%$, respectively. The female/male primary enrollment rate rose rapidly, reaching over $90 \%$ by the early 1980 s and remaining above the comparator throughout (Figure 4f). In contrast, at the secondary level, the female/male enrollment rate, while rising, remained below the comparator. The adult literacy rate showed significant improvement, from below 60\% in 1970 to $87 \%$ in 2000, consistently well above the comparator. Female/male differences in literacy also narrowed but remained higher than the comparator.

Health expenditure also rose as a percentage of GDP in the 1990s. Physicians per 1,000 people increased at an accelerating rate, from 0.4 per 1000 in 1970 reaching 1.3 per 1,000 in 2000. Increased emphasis on preventative health suggests an improvement in the health priority ratio. Yet health care remained highly uneven geographically, with facilities concentrated in urban areas.

Data on income distribution show fluctuations with an improving trend, the Gini reaching 0.47 in 1994 (Figure 4c). The \$2 a day poverty rate was almost 18\% in 1994, falling to $10 \%$ by 2000 . (The $\$ 1$ day poverty rate was $2.5 \%$ in 1994 ) (Figure 4d).

\footnotetext{
${ }^{6}$ Hershlag, 1988; Onis, 1993.
} 
These changes - notably a rise in social expenditure, an improvement in the female/male education ratio and an improvement in the household distribution of income - led to improved levels of HD. The infant mortality rate fell by $60 \%$ between 1990 and 2000 (Figure 4b). The under-5 year mortality rate followed the same pattern, with a 58\% fall. Until 1990, Turkey's performance on both indicators was worse than the comparator, but after that date it was better. Life expectancy at birth improved by four years between 1990 and 2000, reaching seventy by 2000, improving relative to the comparator.

\section{Continued relative weakness in economic growth: 1990s}

Despite the increase in the investment rate of the 1980s, the improvements in HD over the 1990s and, economic reforms, economic growth worsened and remained well below the comparator during the 1990s.

The gross investment rate remained at around $20 \%$ over this decade, despite some increase in foreign direct investment. The export ratio continued to rise reaching $24 \%$ by the end of the 1990 s and export diversification continued, with a fall in primary exports, from $32 \%$ of total exports in 1990 to $18 \%$ by 2000 . While textiles remained broadly constant as a share, high tech exports rose from $3.6 \%$ to $7.7 \%$ of the total.

Financial instability continued in the 1990s, with high budget deficits and inflation, and major financial crises in 1994 and 1999. These and the subsequent deflationary policies meant that growth in the 1990s fluctuated sharply and remained modest at $1.7 \%$ per capita p.a. (Figure $4 a$ ).

\section{Conclusion}

Turkey was unable to move into a virtuous cycle category, despite the improvement in HD and some substantial economic reforms, as her growth fluctuated markedly and was not sustained, largely because of recurrent financial crises associated with budgetary laxity. However, the impact of improved HD was felt in rising FDI and investment rates as well as export growth and diversification. With improvements in financial management and greater economic stability, together with more generous treatment by the international community in response to the prevailing turmoil in the Middle East, Turkey may well be able to translate her good HD into good economic growth and thus enter the virtuous cycle.

\section{4. Failure to sustain economic growth without HD improvements: Pakistan and Nigeria}

It might seem that a plausible route to achieving a virtuous cycle would be first to promote economic growth, and with the resources so generated, promote HD, i.e. moving from vicious to virtuous cycles via the EG-lopsided category in a parallel way to the HD-lopsided route. Yet the empirical evidence suggests this is not a viable possibility and countries that enter the EG-lopsided category do so only temporarily and virtually always fall back into a vicious cycle. To understand why this is likely to happen we explore the two examples of Nigeria and Pakistan.

\section{Pakistan: \\ Introduction}

In 1960 Pakistan was a low-income country with life expectancy of only 43 years. It experienced uneven but relatively high growth in the 1960s, putting it in the 
EG-lopsided category. But it remained relatively weak in HD and fell into a vicious cycle during the 1970s, where it remained up to the end of the century. In the 1980showever, the growth rate recovered, associated with a boom in textile exports, but fell back again in the 1990s.

Pakistan's government has been dominated by the military, despite a few democratic interludes; moreover, landlords have enjoyed formidable political power, frustrating fiscal and other reform efforts throughout the country's history. Factors accounting for the poor HD performance include extremely high military and low social expenditures, together with poor priority ratios. There has been consistent discrimination against females in education as well as in other areas. Pakistan also has had a poor and worsening income distribution. A weak HD performance handicapped economic growth, as indicated by relatively low investment rates and the failure to diversify output and exports.

\section{Good growth but failure to improve HD: 1960s}

Pakistan had a relatively poor performance on HD, even in the early period when it experienced good economic growth with per capita economic growth of over $4 \%$ in the 1960s, double the comparator. Income distribution improved during the 1960s, the Gini falling from 0.38 to 0.33 (Figure 5c). However, land distribution remained highly unequal, with a Gini of 0.63 in the 1960s.

Tax revenue, as a proportion of GDP, remained at around 10\% during the 1960s, below the comparator. Military expenditure accounted for over half of total expenditure, rising to $63 \%$ at one point, while expenditure on education was around $15 \%$ of the total and health below $5 \%$. As a proportion of GDP, education accounted for less than $2 \%$ in the 1960 s, and health less than $0.5 \%$ (Figure 5e). Government social expenditure, moreover, was poorly allocated from an HD perspective. In the health sector the ratio of nurses to doctors never exceeded 0.4 between 1960 and 1980, compared to 0.9 for all developing countries (Federal Bureau of Statistics, 1990, p209). Primary education accounted for just one third of the total and tertiary education for between a fifth and a quarter. In addition, women were particularly poorly treated. In secondary education, for example, female enrollment was around $5 \%$ of males during the 1960 s, compared with a ratio of around $20 \%$ for developing countries generally.

HD outcomes were consequently poor. Overall literacy rates were extremely low, at $21 \%$ in 1970 , less than half that of developing countries generally, with female literacy rates at just $9 \%$ in 1970 . Low literacy rates and the weak position of women, as well as a hostile attitude towards family planning on the part of the government, accounted for continued high fertility rates. The poor HD performance was reflected in high infant mortality rates which fell less rapidly over time than in developing countries as a whole. Pakistan's infant mortality rate at 139 was about the same as the comparator in 1960 but in 1970 it was 116, compared with 105 for the comparator (Figure 5b). 


\section{Pakistan Figures}
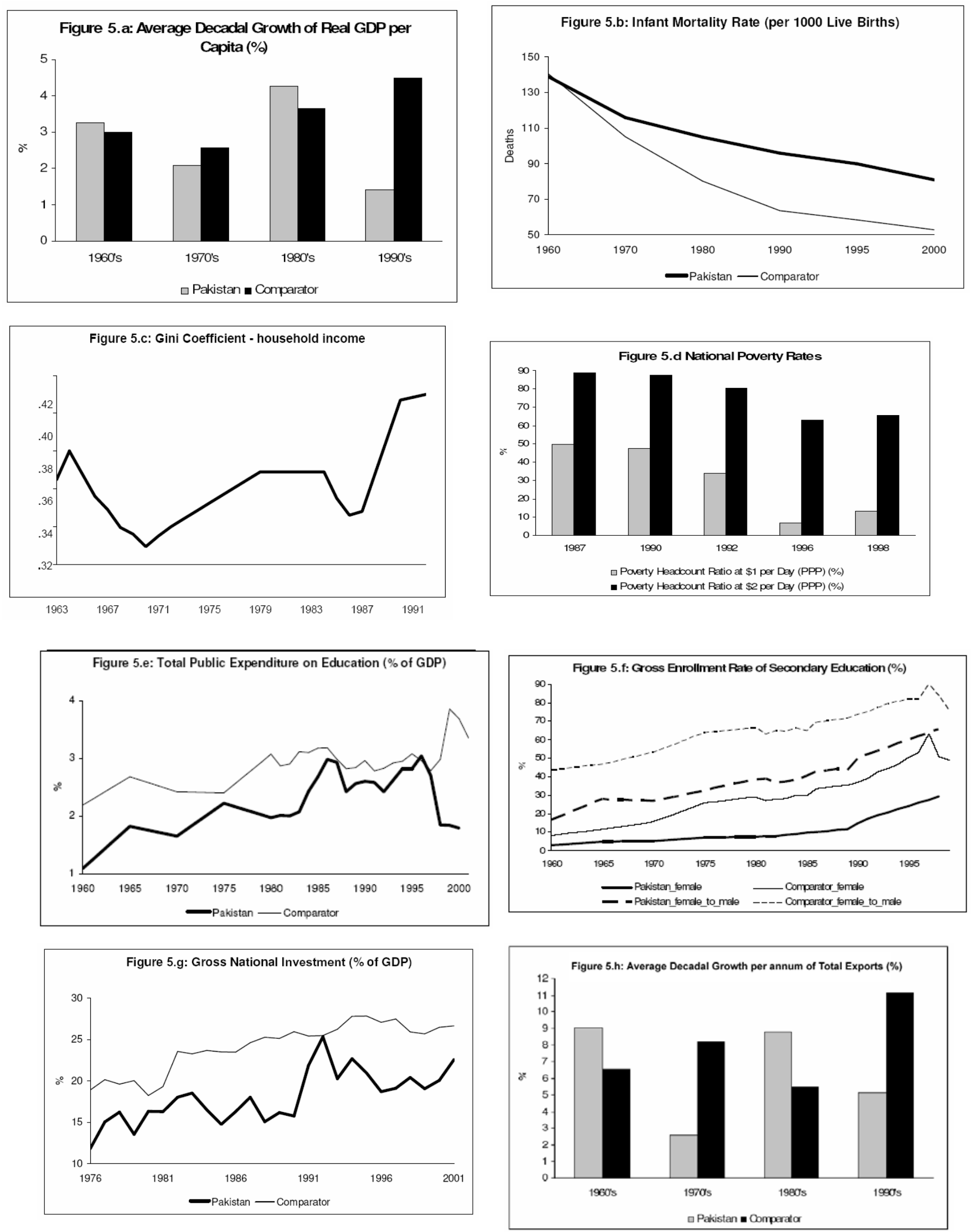


\section{Poor HD handicaps the sustainability of economic growth: 1970s}

The low levels of HD prevented the maintenance of the growth rates of the 1960 s - which fell back to $1.5 \%$ p.a. in the 1970s, well below the comparator. There were deficiencies in the availability of skilled labor and managerial capabilities and the continued poor education levels contributed to low labor productivity (Noman 1997). The investment rate was also relatively low, ranging between 12 and 16\%, well below the comparator, partly due to very low domestic savings and to the negligible levels of foreign direct investment (Figure 5g). Lack of FDI was partly attributable to the weak education and skill levels of the labor force. Low levels of HD also affected the composition of output and exports. While agriculture declined as a proportion of GDP, industry remained broadly stable at $20 \%$ of GDP, and services rose. Textile exports also remained roughly constant as a share of the total at about one-third, while there were negligible high-tech exports. During the 1970s overall export growth was very low and remained well below the comparator until the end of the century (Figure 5h).

The decline in growth in the 1970s, the worsening income distribution and the continued neglect of HD, meant that the poor performance on HD continued. Gross enrollment in primary education in the 1980s was just 40\%, compared with over $100 \%$ for the comparator, and both secondary enrollment and the female/male balance continued to be much worse than the comparator. Literacy rates, infant mortality rates and life expectancy all also continued to be below the comparator.

\section{The vicious cycle continues: 1980s and 1990s}

Growth recovered to some extent in the 1980s, partly due to an export boom associated with economic reforms. Domestic savings rose from the mid-1980s and FDI also rose, from a very low level to $1.2 \%$ of GDP in 1995 but fell back to $0.5 \%$ in 2000 . The gross national investment rate was around $15 \%$ in the 1980 s, and rose to just over $20 \%$ by the end of the 1990s. The sectoral composition of exports changed towards industrial products, mainly textiles, which rose from 33\% in 1980 to $47 \%$ in 1990. For the decade, export growth was $3.4 \%$ p.a., close to the comparator.

Once again, however, somewhat better EG did not translate into improved HD. While government revenue and expenditure as a proportion of GDP were higher in the 1980 s than the 1970 s, approaching the comparator rate at around $13.5 \%$, the share of education and health increased but remained below the comparator. Military expenditure as a share of the total, which had declined in the 1960s and 1970s, once again rose, reaching $38 \%$ of the total by 1990 , substantially above the shares of health and education, taken together; in addition, debt service rose to 39\% by 1985 . Enrollment rates improved but still continued to lag behind the comparator. The female/male ratio for primary education enrollment was just 48\% in 1990 and the secondary ratio $50 \%$, both substantially worse than the comparator. As a consequence, the adult literacy rate continued to lag, at less than half the comparator throughout the 1980s and the Pakistan/comparator gap in infant mortality widened substantially.

As before, weak HD handicapped economic growth, which fell back in the 1990 s to $1.3 \%$ p.a., compared with a growth rate of over $4 \%$ for the comparator (Figure 5a). Export growth slowed, the investment rate fell, FDI flows were low, all much below the comparator, while the composition of output and exports changed little. Weak economic growth, together with a worsening in income distribution in the late 1980s, again translated into poor HD. Government expenditure fell back as a proportion of GDP, military expenditure maintained its share at 39\%, debt service 
took a rising share and the share of education fell back from $20 \%$ in 1990 to $16 \%$ in 2000, although the health share rose a little.

By 2000, after four decades of weak HD improvement, the literacy rate was still only $40 \%$, female literacy $25 \%$, life expectancy 63 , and the infant mortality rate 81, all but life expectancy substantially worse than the comparator.

\section{Conclusion}

Pakistan is a good example of how economic growth cannot be sustained without improving HD. Spurts of economic growth in the 1960s and 1980s were followed by weak growth, as poor HD impeded output and export diversification and deterred investment. Four factors largely accounted for the poor HD: low levels of total revenue due to the inability to tax agriculture, high military expenditure, poor income distribution associated with a failure to implement land reform, and persistent severe discrimination against women. Behind these factors lay the continued dominance of the combined power of the landlords and the military, frustrating serious reform.

\section{Nigeria: \\ Introduction}

Nigeria represents another case illustrating a fallback from EG-lopsided to vicious cycle performance. Nigeria experienced EG-lopsided development in the 1960s and early 1970s, and fell back into a vicious cycle thereafter. Her development has been dominated by three factors: political instability, domination of the political system by the military for much of the time, and the emergence and then dominance of the oil industry. While oil resources initially generated economic growth, HD expenditures were neglected, and the effects of the transition to an oil economy worsened income distribution and led to the neglect of non-oil productive activities, especially agriculture, as well as high levels of rent-seeking and corruption.

\section{Growth without HD: 1960s and 1970s}

In the 1960s and for much of the1970s, Nigeria experienced modest growth, based on the export of agricultural commodities and import-substituting industrialization. Savings and investment rates were quite high, above the comparator, until the 1980s (Figure 6g). Export growth was good, at over 13\% p.a. in the 1960s and almost $9 \%$ in the 1970s. However, the composition of exports continued to be dominated by primary commodities, at over $95 \%$ of the total - first, based on agriculture, but, by the end of the 1970s, oil had completely displaced agriculture. Agricultural exports were eliminated and Nigeria became a significant importer of food. Economic growth was $2.2 \%$ per capita p.a. in the 1960 s, slightly above the comparator, and 1.8\% p.a. in the 1970s (Figure 6a).

Nigeria's economic growth, however, was not translated into progress on HD. Income distribution appears to have been highly unequal, with estimates of the Gini Coefficient ranging between 0.5 and 0.6 in the early 1970s, although data may not be reliable (Figure 6c). Government expenditure as a proportion of GDP was extremely low - around $6 \%$ in the 1960 s and only around $10 \%$ in the 1970 s - seriously affecting the capacity of the government to devote resources to HD activities. In addition, military expenditure rose to $40 \%$ of total government expenditure by 1970 , associated with the 1967-70 Biafran civil war. The proportion spent on education was above 


\section{Nigeria Figures}
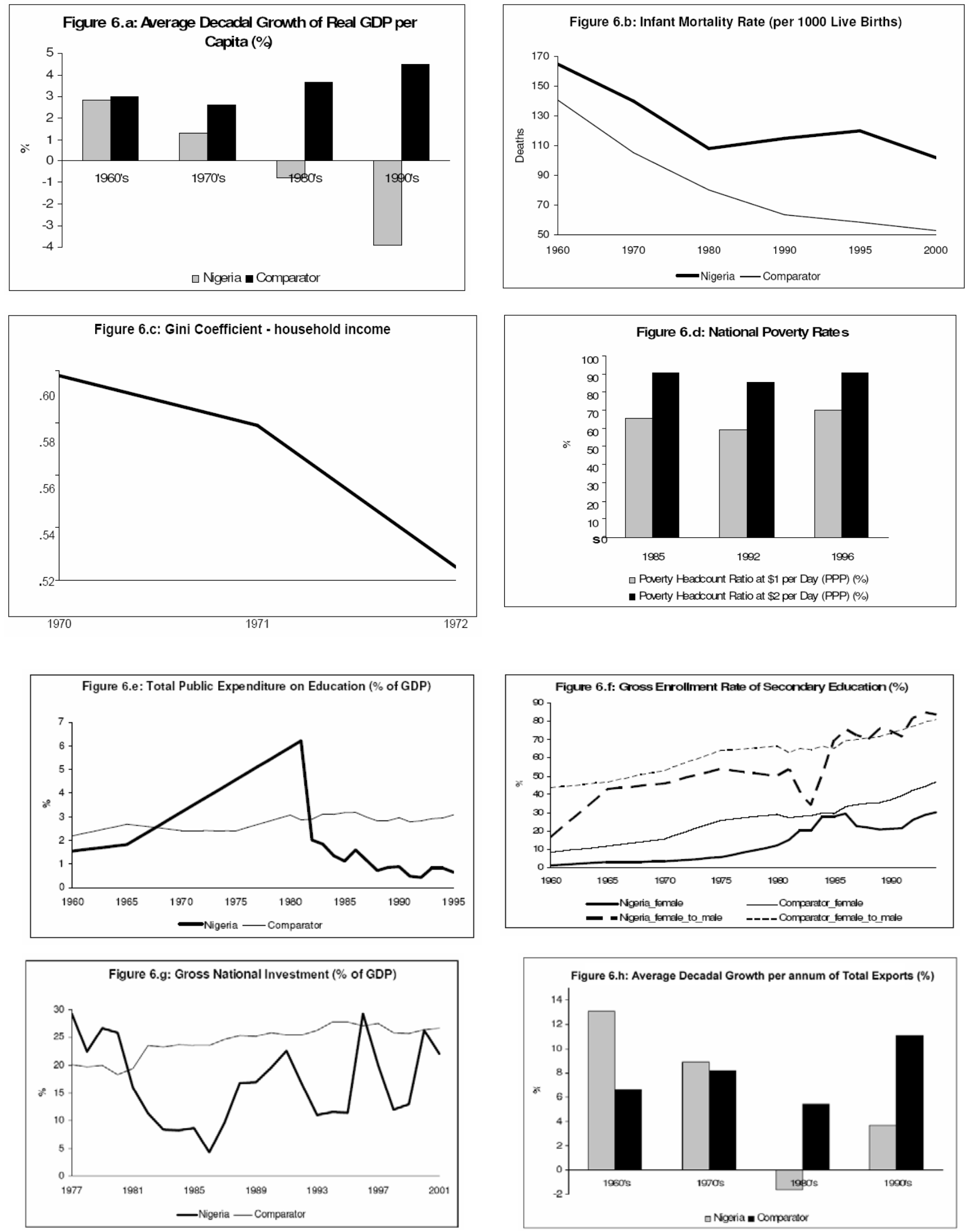
average until 1980 but it fell sharply thereafter. As a proportion of GDP, public education expenditure was low in the 1960 s, ranging from $1.5 \%$ to $3 \%$, but peaked at $6 \%$ in the 1970s before falling precipitously (Figure 6e). Gross primary and secondary enrollment rates rose slowly until the mid-1970s. Gross primary enrollment rates were well below the comparator until 1975, reaching just 50\% in 1975, and secondary education enrollment was only 8\% in 1975. However, from 1975 to 1980 there was a big rise in education expenditure and enrollments reached 95\% (primary) and 18\% (secondary). In both cases, the female/male ratio was, however, well below the comparator. The adult literacy rate remained very low, 20\% in 1970, lagging significantly behind the comparator as well as neighboring African countries, with female literacy only one-third of the male rate.

Health expenditure was around 5\% of government expenditure in 1968, or about $0.5 \%$ of GDP. The infant mortality rate was 165 in 1960, falling to 108 by 1980, significantly worse than the comparator. Life expectancy was also much worse - 46 in 1980, compared with 59 for the comparator. Overall, there were some improvements in HD over the two growth decades of the 1960s and 1970s, but overall HD levels remained very low.

\section{Poor HD contributes to growth failure in the 1980s and 1990s}

From 1980 onwards, per capita economic growth was negative despite the oil bonanza. The poor achievement on HD was a major contributing factor, affecting the quality of the labor force and managerial capacity. While foreign direct investment, associated with the oil industry, was somewhat above that of the comparator, overall investment remained below the comparator and collapsed in the 1980s. The dominant influence on Nigeria's weak economic performance has been the corrosive influence of oil and the poor management of the oil economy, the latter itself in part a direct effect of weak HD. Oil continued to dominate the economy, while both agriculture and industry stagnated. Gross investment fluctuated, reaching over 25\% in some years and falling to below $10 \%$ in others (Figure 6g). FDI fluctuated between $1.2 \%$ and 3.8\% of GDP, mainly associated with the oil industry. A major factor impeding economic recovery was almost continuous political instability of one kind or another, marked by a succession of coups and communal strife. Economic growth was minus $1.8 \%$ p.a. in the 1980s and remained slightly negative in the 1990s (Figure 6a).

Such poor economic growth in turn undermined HD performance. Total government expenditure rose as a proportion of GDP, especially towards the end of the 1990s. However, most of it was devoted to debt service which took $64 \%$ in 1995 , while military expenditure accounted for $6.3 \%$, education $5.9 \%$ and health $1.8 \%$ (in 2000). As a percentage of GDP, military expenditure amounted to $2.7 \%$ in 1977 , falling to $0.7 \%$ in 1986 . Education expenditure was just $1.13 \%$ of GDP in 1985, falling to $0.65 \%$ in 1995 , while public health expenditure was only $0.4 \%$ of GDP in 2000 (Figure 6e). Gross enrollment rates in both primary and secondary education rose from 1980 to 1985 but fellover the 1980s and 1990s as a whole, partly due to the fall in incomes and rising poverty rates. The $\$ 1$ a day poverty rate rose from $65 \%$ in 1985 to nearly $70 \%$ in 1996, while the $\$ 2$ a day rate was $91 \%$ in 1985 and still the same in 1996 (Figure 6d).

Despite the worsening enrollment ratios, adult literacy continued to rise over these decades and reached $64 \%$ by 2000 , still below the comparator of $75 \%$. Life expectancy showed very little change: it was 46 years in 1980 and 47 years in 2000, while the comparator reached 64 by 2000 . The infant mortality rate fell from 108 in 
1980 to 102 in 2000, twice the level of the comparator (Figure 6b). These very poor health results were partly due to the spread of AIDS.

\section{Conclusion}

Nigeria is another example demonstrating why economic growth is not sustainable without improvements in HD, although, in this case, other factors, particularly the impact of oil and the unstable political situation, were also major contributors. The poor performance of HD - which continued even after the oil bonanza arrived - is particularly notable in view of the accompanying spurt in government revenue. Nigeria represents an extreme example of the difficulty of managing an oil economy, associated with a worsening income distribution, increased corruption and rent-seeking ${ }^{7}$. The political situation in Nigeria - particularly the dominance of the military for most of the period - undoubtedly contributed to these problems and to the continued neglect of HD.

\section{CONCLUSIONS}

Our aim in this paper has been to explore how countries can move towards a virtuous cycle position in which improvements in HD accompany and support higher EG and this, in turn, contributes to further HD improvements.

Our first and most important conclusion is that a country must place priority on HD and cannot move towards the virtuous category by giving sole priority to EG. The experience of Nigeria and Pakistan illustrates how success on EG is only temporary unless supported by improved HD. Although both countries were able to grow reasonably well for a short while, fuelled by textiles in the case of Pakistan and by oil in Nigeria, neither was able to translate such growth into improved HD. These failures on HD handicapped future growth because in each case the system lacked the human capabilities to generate innovation and bring about structural transformation of the economy. Underlying the poor performance of HD in both countries was the dominance of the military, leading to high military expenditure, complemented, in the case of Pakistan, by a feudal social structure and severe discrimination against women. In Nigeria, the oil economy corrupted politics and cushioned decision-makers from having to introduce needed economic reforms (Ranis and Mahmood 1992). In both countries the result was an unequal distribution of income, a low level of taxation, and a low allocation of expenditure to education and health.

It follows that in order to achieve a virtuous cycle it is important to understand how to improve HD. This is our second major conclusion. Such an improvement was achieved by China, Vietnam, Chile and Turkey. These successful cases demonstrated a variety of processes which were responsible for the improved HD. Almost all the countries that succeeded in promoting HD had reasonably high tax revenues and allocated a high proportion of total expenditure to education and health. The one exception was Chile under Pinochet where a fairly low revenue ratio and a low allocation to social expenditure were overcome by a good priority ratio. In general, too, all the successful countries reduced female/male gaps in education. It should be noted that these countries' income distribution experiences were varied; China and Vietnam had a rather equal distribution but Chile and Turkey did not. The political

\footnotetext{
${ }^{7}$ See Auty, 2001,
} 
economy conditions also varied sharply. China and Vietnam were both socialist, while Chile had periods of social democracy and periods of military dictatorship, as did Turkey. What this seems to indicate is that almost any country can achieve improved HD. It does not require some unique political or social setting.

Our third lesson is that, while HD improvement is essential for moving into the virtuous cycle, EG does not follow automatically from improved HD, as shown in the case of Turkey and some of Chile's history. Turkey has moved into an HDlopsided position and thus has the possibility of achieving a virtuous cycle but it seems to have been held back to date mainly by financial instability and to some extent by internal conflicts. The country experience indicates that in order to take advantage of the platform provided by improved HD some economic reforms are usually necessary, as demonstrated by China, Vietnam and Chile. But some reforms can also be counterproductive as shown by the results of the highly deflationary policies of Chile in the 1980s and those of the financial liberalization policies and resulting temporary financial instability in Chile and Turkey. In addition, as shown by all the countries that achieved good growth as well as good HD improvements ,high investment rates are essential, state-led initially in the cases of China and Vietnam, while Chile and, in later phases, China and Vietnam relied increasingly on private investment, domestic and foreign. It seems likely that policies to promote R\& D and linking it to the growth of the economy also contributed to the effective translation of improved HD into EG.

Overall, we find that improvements in HD are not only essential in order to move a country towards a virtuous cycle, but they are also potentially universally achievable. Given appropriate economic policies, improved HD then allows a transition into a virtuous cycle. Moreover, once a country has good HD it can overcome major disruptions and changes in social systems as shown in China, Vietnam and Chile. 


\section{References:}

Adelman, Irma and David Sunding (1988). "Economic Policy and Income Distribution in China,” Chinese Economic Reform, ed. Reynolds, Bruce L., pp. 154-171. Boston: Academic Press.

Auty, R.M. (2001), ed., Resource Abundance and Economic Development, Oxford University Press.

Benedict, Peter (1974).; Tumertekin, Erol; Mansur, Fatma. Turkey: Geographic and Social Perspectives. Leiden: E.J.Brill.

Beresford, Melanie (1989). National Unification and Economic Development in Vietnam. London: Macmillan.

Boothroyd, Peter and Pham Xuan Nam, eds. (2000) Socioeconomic Renovation In Viet Nam : The Origin, Evolution, And Impact Of Doi Moi. Ottawa: International Development Research Centre.

Boratav, Korkut (2003). Turkiye Iktisat Tarihi 1908-2002. Ankara: Imge Kitapevi Yayinlari,

China Data Online 2004. University of Michigan. http://chinadataonline.org/

China Human Development Report (CHDR), (1997). New York: Oxford University Press.

China Human Development Report -Transition and the State (CHDR) 1999. New York: Oxford University Press.

China: A Statistics Survey in 1985 (CSS). Beijing: China Statistical Information and Consultancy Service Centre.

Cumhuriyet Ansiklopedisi 1923-2000, Cilt 4 1981-2000. (2002). Yapi Kredi Kultur Sanat Yayincilik Ticaret ve Sanayi A.S., Istanbul.

Economic Indicators of Turkey 1982-1986. (1986). Economic Research Department [Ankara]. Ankara: Turkiye Is Bankasi A.S.

Economic survey of free Viet-Nam: Statistical analysis data through 1959 (ESFV 1960). Saigon: Dept. of National Economy.

Expanding choices for the rural poor: human development in Viet Nam (ECRP 1998). Hanoi, Vietnam: United Nations Viet Nam.

Fforde, Adam, ed. (1997). Doi Moi:Ten Years After The 1986 Party Congress. Canberra: Dept. of Political and Social Change, the Australian National University. 
Glewwe, Paul (1998). Provision Of Health Care And Education In Transitional Asia: Key Issues And Lessons From Vietnam. Helsinki, Finland : UNU World Institute for Development Economics.

Glewwe, Paul, and Nisha Agrawal, et al, eds. (2004). Economic Growth, Poverty, And Household Welfare In Vietnam. Washington, DC: World Bank.

Griffin, Keith, ed. (1998) Economic Reform In Vietnam. Houndmills, Basingstoke, Hampshire: Macmillan.

Gulati, A., S. Fan and S. Dalafi (2005), 'The Dragon And The Elephant: Agricultural And Rural Reforms In China And India', MTID Discussion Paper 87, DSGD Discussion Paper 22, Washington, IFPRI.

Guldner, Mattias, and Susan Rifkin. (1993). "Sustainability in the Health Sector, Vietnam Case Study." Report for Save the Children, U.K. Unpublished.

Hainsworth, Geoffrey B (1999). Localized Poverty Reduction In Viet Nam: Improving The Enabling Environment For Rural Livelihood Enhancement. Vancouver: Centre for Southeast Asia Research.

Hale, William (1981). The Political and Economic Development of Modern Turkey. New York: St. Martin’s Press.

Hershlag, Z.Y. (1988). The Contemporary Turkish Economy. London: Routledge Press.

Jamison, Dean T., Evans, King, etc al. (1984) China: The Health Sector, Washington DC: The World Bank.

Joint Monitoring Programme (2004). "Water and Sanitation Data Query Tool.”

< http://www.wssinfo.org/pdf/country/turkey_wat_02.pdf >

Kilicbay, Prof. Dr. Ahmet m(1984). Turk Ekonomisi: Modeller, Politikalar, Stratejiler. Ankara: Turkiye Is Bankasi Kultur Yayinlari.

Krueger, Anne O. (1992). Turkey: Trade Reforms in the 1980s. San Francisco, California: ICS Press.

Krueger, Anne O. (1974). Foreign Trade Regimes and Economic Development: Turkey New York: NBER.

Looking ahead: a United Nations common country assessment of Viet Nam (1999). Hanoi : United Nations in Vietnam.

Ministry of Health [Turkey] (1994). Hacattepe University Institute of Population Studies, and Macro International Inc.. Turkish Demographic Health Survey 1993. Maryland: Demographic and Health Surveys, Macro International Inc. 
Ministry of Health [Turkey] (1997). Hacattepe University Institute of Population Studies, and Macro International Inc.. Fertility trends, women's status, and reproductive expectations in Turkey : results of further analysis of the 1993 Turkish demographic and health survey. Calvertom, Md.: Macro International, Demographic and Health Surveys, 1997

Nai-ruenn, Chen (1967). Chinese Economic Statistics: A Handbook for Mainland China. Chicago: Aldine Publishing.

Noman,O. (1997). Economic and Social Progress in Asia. Why Pakistan Did not Become a Tiger. OUP. Karachi.

Onis, Ziya (1993). Economic Crisis and Long-term Growth in Turkey. Washington, D.C.: The International Bank for Reconstruction and Development/The World Bank.

Ranis, G. and S.Mahmood. (1992) The Political Economy of Development Policy Change. Oxford. Blackwell.

Ranis, G. and Francis Stewart 2006, "Dynamic Links between the Economy and Human Development,” in DESA Working Paper No.8, 2006, forthcoming.

Social Indicators of Development (SIDA 1994). Baltimore: Johns Hopkins University Press.

Statistical data of the Socialist Republic of Vietnam, 1976-1990 (SDSRV 1991). Hanoi: Thóng ke.

Statistical Yearbook of China, 1983. Beijing: State Statistical Bureau.

The Economist Intelligent Unit (1987). Country Profile: TURKEY 1987-88 London: The Economist Intelligence Unit Limited.

The Economist Intelligent Unit (1991). Country Profile: TURKEY 1991-92. London: The Economist Intelligence Unit Limited.

The Economist Intelligent Unit. Country Profile (1993). TURKEY 1993-94. New York: The Economist Intelligence Unit Limited.

The Economist Intelligent Unit. Country Profile (1996). TURKEY 1996-97. New York: The Economist Intelligence Unit Limited.

The Economist Intelligent Unit. Country Profile (1988). TURKEY 1997-98. New York: The Economist Intelligence Unit Limited.

The Economist Intelligent Unit. Country Profile (1999). TURKEY 1999-00. New York: The Economist Intelligence Unit Limited.

Tr`ân, Hoàng Kim (1992). Economic sectors in Vietnam: situation, tendency and solutions. Hanoi: Th'ông kê. 
United Nations Development Programme (1990). Human Development Report (HDR)1990. New York: Oxford University Press.

United Nations Development Programme (2001) Human Development Report 2001 Doi Moi Process and Human Development.

United Nations Development Programme (2003) Human Development Report (HDR) 2003. New York: Oxford University Press.

US Department of State, Background Note: Vietnam: http://www.state.gov/r/pa/ei/bgn/4130.htm (accessed Sept 4, 2006).

Utkulu, Utku (2001). Turkey since 1970 Politics, Economics, and Society. New York: Palgrave Press.

Vietnam statistical data in the 20th century (VSD 2004). Hanoi: Nhà xu'ât b?an Th'ông kê.

World Bank (2003). "Health, Nutrition, and Population (HNP) Statistic Database.” 2002. <http://devdata.worldbank.org/hnpstats/>.

World Bank (2004). “World Development Indicators” (WDI) Database. $<$ http://www.worldbank.org/data/wdi2004>.

World Bank (2004). "World Development Indicators” (WDI) Database. $<$ http://www.worldbank.org/data/wdi2004>.

World Bank Group (2004). “Country Classification: Country Groups.” 2004. <http://www.worldbank.org/data/countryclass/classgroups.htm\#Low_income>

Year of Publication (HDR 2001). Hanoi: National Centre for Social Sciences and Humanities.

Yenal, Oktay (2003). Cumhuriyet’in Iktisat Tarihi. Istanbul: Homer Kitapevi ve Yayincilik Ltd. Sti.

Zhongguo min zu tong ji (1991). (China National Statistics), 1949-1990. Beijing: China Statistics Bureau. 